\title{
CHILDREN'S FRIENDLY EDUCATION THROUGH THE "MORNING STORY" SCHOOL CULTURE AS AN EFFORTS TO STRENGTHEN STUDENT CHARACTERS IN SD 01 KANIGORO MADIUN
}

\section{Titin Kuntum Mandalawati}

Universitas PGRI Madiun

mandalawatititin@gmail.com

\begin{tabular}{l} 
Article History \\
\hline accepted 09/07/2018 \\
approved 01/08/2018 \\
published 17/09/2018
\end{tabular}

\section{Keywords}

Pendidikan ramah anak, kultur morning story, karakter

\begin{abstract}
Penelitian ini bertujuan untuk mengetahui 1). Mengetahui pola pendidikan ramah anak melalui kultur "morning story" di SD 01 Kanigoro, ; (2). Menganalisis relasi kultur "morning story" pada pembentukan karakter siswa di SD 01 Kanigoro, ; (3). Menganalisis peran guru, dan orangtua dalam pendidikan ramah anak melalui kultur "morning story" di SD 01 Kanigoro. Paradigma penelitian ini adalah kualitatif dengan menggunakan pendekatan fenomenologis. Subjek penelitian adalah kepala sekolah, guru, siswa, dan orangtua. Penentuan subjek penelitian dilakukan dengan teknik purposive sampling. Teknik pengumpulan data menggunakan observasi, wawancara, dan dokumentasi. Analisis data dalam penelitian menggunakan Model Miles dan Huberman yakni pengumpulan data, reduksidata, penyajian data, dan kesimpulan. Hasil penelitian menunjukkan bahwa: (1). Pola pendidikan ramah anak melalui kultur "morning story" dapat mengeksplorasi potensi, bakat dan kemampuan berkomunikasi siswa, serta memotivasi siswa untuk tampil di depan publik, dan memunculkan keberanian serta kepercayaan diri siswa. (2). Kultur "morning story" memiliki relasi positif terhadap karakter siswa di SD 01 Kanigoro Madiun, yakni karakter cinta tanah air, bertanggungjawab, kejujuran, keakraban, peduli lingkungan, toleransi, dan kedisiplinan. (3). Guru dan orangtua memiliki peran yang sangat penting sebagai model dan tauladan bagi siswa dalam pembentukan kultur "morning story" di sekolah maupun dirumah.
\end{abstract}

Social, Humanities, and Education Studies (SHEs): Conference Series p-ISSN 2620-9284 https://jurnal.uns.ac.id/shes e-ISSN 2620-9292 


\section{PENDAHULUAN}

Pendidikan merupakan salah satu gerbang menuju kemajuan dan kemakmuran peradapan suatu bangsa, melalui pendidikan yang berkualitas akan membentuk kader-kader bangsa yang berpotensi dan mampu bersaing di kancah internasioanl. Pendidikan yang berkualitas haruslah pendidikan yang ramah anak, dimana anak bukan hanya subyek dalam pendidikan namun anak sebagai subyek dan obyek dalam pendidikan, dalam hal ini anak menjadi aktor utama dalam pendidikan. Sehingga pendidikan tidak diperkenankan adanya unsur paksaan, tekanan dan hukuman pada anak. Sekolah diupayakan melaksanakan pendidikan yang penuh asah asih dan asuh yang memberikan perlindungan dan keamanan kepada anak, sehingga anak merasa nyaman dan senang belajar di sekolah.

Pendidikan ramah anak harus mengutamakan kasih sayang dan cinta kepada siswa, dimana siswa dapat mengembangkan potensi dan kemampuannya secara maksimal tanpa tekanan dari orangtua dan guru. Namun kenyataan di lapangan justru sekolah menjadi tempat yang tidak ramah bagi anak, dimana muncul banyak sekali kekerasan, bullying, dan kenakalan anak. Hal ini berdasarkan pada data dari Komisi Perlindungan Anak Indonesia (KPAI) mencatat pada tahun 2015, telah terjadi 6006 kasus kekerasan pada anak di Indonesia. Angka ini meningkat signifikan dari tahun 2010 yang hanya 171 kasus. Sementara pada tahun 2011, tercatat sebanyak 2179 kasus, 2012 sebanyak 3512 kasus, 2013 sebanyak 4311, dan 2014 sebanyak 5066 kasus. Dari 6006 kasus, sebanyak 3160 kasus kekerasan terhadap anak terkait pengasuhan, 1764 kasus terkait pendidikan, 1366 kasus terkait kesehatan dan narkoba, dan 1032 kasus disebabkan oleh cyber crime dan pornografi.(http://nasional.news.viva.co.id/news/read). Sementara pada tahun 2016-2017 kasus kekerasan anak yang terjadi di lingkup sekolah semakin meningkat secara signifikan. Hal ini harus menjadi perhatian banyak pihak menginggat sekolah seharusnya menjadi tempat kegiatan yang nyaman dan aman bagi siswa untuk melakukan aktivitas pendidikan,dimana anak bebas berkreasi dalam belajar dengan suasana lingkungan pendidikan yang penuh dengan kasih sayang dan ramah anak. Karena pada hakikatnya manusia diciptakan oleh Tuhan dengan membawa fitrah yang merdeka, mempunyai hak dan kebebasan yang telah melekat pada dirinya, sehingga pembelajaran yang dilakukan harusnya menyenangkan, penuh kasih sayang, dan mampu mengeksplorasi kemampuan siswa secara maksimal.

Sekolah harus dijadikan pelopor dalam pendidikan ramah anak, sekolah ramah anak yakni sebuah konsep sekolah yang terbuka, berusaha mengaplikasi pembelajaran yang meperhatikan perkembangan psikologis siswanya. Mengembangkan kebiasaan belajar sesuai dengan kondisi alami dan kejiwaan anak. (Kristanto, 2011: 41). Pandangan Ngadiyo (2013: 18) bahwa sekolah ramah anak adalah sekolah yang anti diskriminatif, menerapkan PAIKEM, perhatian dan melindungi anak, lingkungan yang sehat, serta adanya partisipasi orang tua dan masyarakat.

Sekolah harus memiliki strategi pendidikan yang ramah anak, salah satunya dengan penerapan kultur sekolah. Kultur sekolah menurut pandangan Darmiyati (2011: 137) merupakan konteks di belakang layar sekolah yang menunjukkan keyakinan, nilai, 
norma, dan kebiasaan yang telah dibangun dalam waktu yang lama oleh semua warga dalam kerja sama di sekolah. Senada dengan yang dikemukakan oleh Zamroni (2011: 297) bahwa budaya sekolah adalah merupakan suatu pola asumsi-asumsi dasar, nilai-nilai, keyakinan-keyakinan, dan kebiasaan-kebiasaan yang dipegang bersama oleh seluruh warga sekolah, yang diyakini dan telah terbukti dapat dipergunakan untuk menghadapi berbagai problem dalam beradaptasi dengan lingkungan yang baru dan melakukan integrasi internal, sehingga pola nilai dan asumsi tersebut dapat diajarkan kepada anggota dan generasi baru agar mereka memiliki pandangan yang tepat bagaimana seharusnya mereka memahami, berpikir, merasakan dan bertindak menghadapi berbagai situasi dan lingkungan yang ada.

Pendidikan ramah anak juga diterapkan di SD 01 Kanigoro melalui Kultur sekolah "morning story" atau cerita pagi. Guru memberikan bimbingan dan pengarahan kepada siswa untuk dapat mengeksplorasi kemampuannya dalam bercerita dan berbicara di depan publik. Kultur sekolah "morning story" dilaksanakan oleh siswa dengan penuh kesenangan dan kegembiraan, sekaigus melatih kepercayaan diri siswa berkomunikasi di hadapan publik. Kultur sekolah "morning story" yang diterapkan di sekolah diharapkan dapat membentuk karakter siswa. Namun dalam implementasinya muncul beberapa kendala-kendala baik dari guru, siswa, orangtua, dan kepala sekolah. Selain itu Peneliti ingin mengetahui (1). Pola pendidikan ramah anak melalui kultur "morning story" di SD 01 Kanigoro Madiun, ; (2). Menganalisis relasi kultur "morning story" pada pembentukan karakter siswa di SD 01 Kanigoro Madiun, ; (3). Menganalisis peran guru, dan orangtua dalam pendidikan ramah anak melalui kultur "morning story" sebagai upaya penguatan karakter siswa di SD 01 Kanigoro Madiun. Oleh karena itulah peneliti tertarik meneliti mengenai Pendidikan Ramah anak melalui kultur sekolah "morning story" sebagai upaya penguatan karakter siswa di SD 01 Kanigoro Madiun.

\section{METODE PENELITIAN}

Penelitian ini menggunakan metode kualitatif dengan pendekatan fenomenologi. Fenomenologi dipilih untuk mengungkap fenomena-fenomena dan gejala yang ditimbulkan dalam Pendidikan Ramah anak melalui kultur sekolah "morning story" yag diterapkan disekolah dalam rangka pengembangan karakter siswa. Peneliti memasuki wawasan persepsi informan, mengetahui pengalaman informan, dan melibatkan fenomena serta mencari makna dari pengalaman informan.

Subjek penelitian dalam penelitian ini yakni kepala sekolah, guru, siswa, dan orang tua. Penentuan subyek penelitian dilakukan dengan teknik purposive sampling. Teknik pengumpulan data menggunakan observasi, wawancara, dan dokumentasi. instrumen penelitian dalam bentuk pedoman wawancara, pedoman observasi, catatatan lapangan dan gambar foto sebagai dokumentasi penelitian. Analisis data dalam penelitian menggunakan Model Miles dan Huberman yaitu pengumpulan data, reduksi data, penyajian data, dan kesimpulan. 


\section{HASIL PENELITIAN DAN PEMBAHASAN}

Hasil penelitian menunjukkan bahwa : (1). Pola pendidikan ramah anak melalui kultur "morning story" yang dilaksanakan setiap hari senin sampai hari kamis dapat mengembangkan kemampuan siswa dalam berbahasa dan berkomunikasi di depan publik. Kulture "morning story" dilakukan oleh siswa secara bergilir dengan cara siswa mendaftarkan diri ke tempat guru dan sebelum tampil di depan siswa akan dilatih oleh guru secara maksimal agar siswa tidak grogi dan berani untuk bercerita. Guru akan menyeleksi siswa manakah yang akan tampil terlebih dahulu dan siswa lain pada hari berikutnya. Siswa yang bercerita didepan kelas hanya 1 anak setiap harinya. Morning story dilaksanakan 20 menit sebelum siswa memasuki ruang kelas, dimana siswa akan berbaris di halaman sekolah dan akan mendengarkan salah seorang siswa bercerita. Pada saat maju siswa bercerita teman-temannya akan mendengarkan dengan baik dan akan ditunjuk secara random salah seorang siswa untuk mendeskripsikan isi dari cerita yang di dengarnya. Bapak Muhammad Nasrulloh seorang guru SD 01 Kanigoro yang telah 15 Tahun bekerja sebagai guru menambahkan bahwa kultur cerita pagi yang dilaksanakan disekolah merupakan sarana siswa untuk mengeskplorasi diri dan menjadikan siswa berani untuk berkomunikasi dan berbicara di depan umum. kultur cerita pagi dilaksanakan setiap hari senin sampai kamis, hari jumat kegiatan jumat bersih dan sabtu literasi. Kultur cerita pagi memberikan nuansa yang berbeda pada sekolah, dimana setiap harinya siswa akan berlatih untuk tampil didepan kelas, menampilkan kemampuannya dihadapan teman-temannya. Hal ini mendorong siswa untuk berani tampil dan meningkatkan kepercayaan diri siswa.

Guru yang melatih siswa pun senantiasa mendorong dan memberikan motivasi kepada siswa untuk dapat mengembangkan potensi dan kemampuan berbahasanya dengan baik. Tujuan sekolah mengadakan Kulture "morning story" agar siswa terbiasa untuk membaca buku, berkomunikasi di depan umum, membiasakan siswa untk berimajinasi dan bereksplorasi, membiasakan siswa untuk memahami etika ketika berbicara di depan publik, membiasakan siswa untuk melatih kepercayaan diri bercerita, mengoptimalkan potensi siswa, memotivasi siswa yang kurang aktif dan malu untuk berbicara ketika di kelas menjadi siswa yang berlatih berani, memperlancar membaca siswa, membiasakan siswa bertanggungjawab terhadap apa yang menjadi tugas nya, menyajikan pembelajaran yang berbeda bagi siswa, dan mengembangkan bakat juga minat siswa dalam belajar

(2) . . Kultur "morning story" memiliki relasi positif terhadap karakter siswa di SD 01 Kanigoro Madiun, dimana "morning story" atau cerita pagi yang diceritakan siswa di depan kelas yang berupa cerita kepahlawanan, cerita dongeng, cerita nabi-nabi, cerita teladan, dan cerita keagamaan yang dapat membangkitkan semangat belajar siswa dan meningkatkan wawasan siswa. Kultur "morning story"memiliki relasi pada karakter karena dapat membentuk karakter siswa menjadi lebih positif, yakni siswa akan memiliki karakter cinta tanah air, siswa lebih bertanggungjawab, melatih kejujuran, keakraban atau komunikasi, siswa menjadi peduli lingkungan sekitar, toleransi, dan kedisiplinan. Pembiasaan "morning story" menjadi kegiatan yang menyenangkan bagi siswa, selain melatih keberanian juga menjadi sarana untuk berkomunikasi dengan teman-teman dan menambah pengetahuan siswa. 
(3). Guru dan orangtua memiliki peran yang sangat penting sebagai model dan tauladan bagi siswa dalam pembentukan kultur "morning story" di sekolah maupun dirumah. Guru membimbing dan melatih siswa untuk tampil bercerita di depan kelas, guru mengajarkan kepada siswa etika dalam berbicara di depan kelas, guru memotivasi siswa untuk berani tampil di depan teman-temannya, guru mengkondisikan kegiatan "morning story" dengan baik dimana audiens atau pendengar tidak diperkenankan ramai sendiri dan harus mendengarkan cerita temannya dengan cermat, dan ketika cerita telah selesai maka audiens secara acak akan dipilih 1 orang untuk mendeskripsikan kembali cerita yang didengarnya. Hal ini akan melatih konsentrasi dan pemahaman siswa pada suatu cerita.

\section{SIMPULAN}

Pendidikan ramah anak yang dilaksanakan oleh SD 01 Kanogoro melalui Kultur "morning story" perlu dilanjutkan dengan tujuan akan meningkatkan potensi belajar siswa, menjadikan siswa merasa nyaman dan senang belakar di sekolah, memupuk rasa cinta siswa terhadap buku, dan memunculkan karakter sosial pada anak. Pendidikan ramah anak melalui Kultur "morning story" memiliki relasi yang sangat erat dengan pembentkan karakter siswa, dimana siswa memiliki karakter cinta tanah air, siswa lebih bertanggungjawab, melatih kejujuran, keakraban atau komunikasi, siswa menjadi peduli lingkungan sekitar, toleransi, dan kedisiplinan. Pendidikan ramah anak melalui Kultur "morning story" perlu mendapatkan dukungan penuh dari guru dan orangtua, dimana guru dan orangtua berkewajiban untuk membimbing mengarahkan dan memotivasi siswa agar tumbuh rasa keberanian dan kepercayaan dirinya untuk berkomunikasi di depan publik. Selain itu guru dan orangtua harus terus membantu siswa dalam mengembangkan potensi, bakat dan minat sehingga siswa dapat mengekplorasi kemampuannya dengan maksimal. Guru dan orangtua perlu saling berkolaborasi untuk menciptakan lingkungan yang nyaman, aman dan kondusif untuk kelancaran siswa dalam belajar.

\section{DAFTAR PUSTAKA}

Darmiyati. 2011. Pendidikan Kartakter dalam prespektif Teori dan Praktik. Yogyakarta : UNY Press

Kristanto, Ismatul Khasanah, Mila Karmila. 2011. Identifikasi model sekolah ramah anak (sra) jenjang satuan pendidikan anak usia dini se-kecamatan Semarang selatan. Jurnal Penelitian PAUDIA. Volume 1 No. 1. e-jurnal. ikippgrismg.ac.id.

Miles, M. B. \& Huberman, M. (1994). Qualitative data analysis: an expanded sourcebook- (2end). SAGA Publication: International Educational and Professional Publisher Thousand Oaks London New Delhi.

Ngadiyo. 2013. Homeschooling, Melejitkan Potensi Anak. Majalah Embun. Edisi 49-V-Rajab 1434 H/Mei 2013.

Undang-Undang Nomor 23 Tahun 2002 Tentang Perlindungan Anak.

Undang-Undang RI No. 20 tahun 2003. Tentang Sistem Pendidikan Nasional. Jakarta: Departemen Pendidikan Nasional

Zamroni. 2011. Dinamika Peningkatan Mutu.Yogyakarta:Gavin Kalam Utama 